Journal of Telenursing (JOTING)

Volume 1, Nomor 1, Juni 2019

e-ISSN : 2684-8988

p-ISSN : 2684-8996

DOI: https://doi.org/10.31539/joting.v1i1.518

\title{
PENGARUH EDUKASI KELUARGA TERHADAP KEMAMPUAN KELUARGA DALAM MERAWAT KLIEN DENGAN ISOLASI SOSIAL
}

\author{
Muhammad Amin ${ }^{1}$, Yoga Saputra ${ }^{2}$, Deoni Vioneery ${ }^{3}$ \\ Universitas Muhammadiyah Bengkulu ${ }^{1,2}$ \\ Sekolah Tinggi Ilmu Kesehatan Surakarta ${ }^{3}$ \\ mamin@umb.ac.id ${ }^{1}$
}

\begin{abstract}
ABSTRAK
Tujuan penelitian ini adalah untuk mengetahui pengaruh pendidikan keluarga terhadap kemampuan keluarga dalam merawat Klien dengan isolasi sosial yang melampaui RSKJ Soeprapto Bengkulu, yang berdomisili di Kota Bengkulu. Penelitian ini merupakan penelitian kuantitatif. Jenis pendekatan penelitian ini adalah penelitian quasi eksperimen dengan rancangan penelitian one-group pre-test and post test design. Hasil penelitian berdasarkan uji analisis didapatkan p value 0,001 $(<0,05)$. Simpulan, ada pengaruh edukasi keluarga terhadap kemampuan keluarga dalam merawat pasien dengan ganguan isolasi sosial di RSKJ Soeprapto Bengkulu.
\end{abstract}

Kata Kunci: Isolasi Sosial, Pendidikan Keluarga, Pengetahuan Keluarga

\section{ABSTRACT}

The purpose of this study was to determine the effect of family education on the ability of families to care for clients with social isolation that surpasses RSKJ Soeprapto Bengkulu, who lives in Bengkulu City. This research is a quantitative research. This type of research approach is a quasi-experimental research design with a one-group pre-test and post-test design. The results of the study based on the analysis test obtained $p$ value 0.001 (<0.05). In conclusion, there is an effect of family education on the ability of families to care for patients with social isolation disorders at RSKJ Soeprapto Bengkulu.

Keywords: Social Isolation, Family Education, Family Knowledge

\section{PENDAHULUAN}

Pembangunan kesehatan bertujuan meningkatkan kesadaran, kemampuan dan kemauan hidup sehat bagi seluruh masyarakat dalam rangka mewujudkan derajat masyarakat yang setinggi-tingginya. Masyarakat diharapkan berpartisipasi aktif dalam memelihara dan meningkatkan derajat kesehatannya sendiri, sehingga masyarakat bukan hanya menjadi sasaran tetapi juga menjadi pelaksana dalam pembangunan kesehatan jiwa. Sesuai dengan visi Departemen Kesehatan RI yaitu masyarakat yang mandiri untuk hidup sehat. Masyarakat yang mandiri untuk hidup sehat adalah masyarakat yang sadar, mampu mengenali dan mengatasi permasalahan kesehatan yang dihadapi sehingga dapat bebas dari gangguan kesehatan, baik yang disebabkan penyakit termasuk gangguan kesehatan akibat bencana, maupun lingkungan dan perilaku yang 
tidak mendukung untuk hidup sehat termasuk masalah kesehatan jiwa (Farid, 2008; dalam Wiyati et al., 2010).

Gangguan jiwa atau skizofrenia adalah respon maladaptif dari lingkungan internal dan eksternal, dibuktikan melalui pikiran, perasaan dan perilaku yang tidak sesuai dengan norma lokal atau budaya setempat dan menganganggu fungsi sosial, pekerjaan dan atau fisik (Dermawan \& Rusdi, 2013).

Data dari WHO pada tahun 2013, terdapat 26 juta penduduk Indonesia mengalami gangguan jiwa. Berdasarkan data tersebut dapat disimpulkan bahwa angka gangguan jiwa di Indonesia mencapai $12 \%$ - 16\% dari populasi penduduk. Gangguan jiwa di Indonesia menjadi masalah yang cukup serius. Berdasarkan data Depkes (2010) ada satu dari lima penduduk Indonesia menderita gangguan jiwa. Hasil Survei Kesehatan Rumah Tangga (SKRT) menunjukan gangguan mental emosional pada usia diatas lima belas tahun adalah 140 orang per 1.000 penduduk dan usia lima sampai empat belas tahun sebanyak 104 orang per 1.000 penduduk (Maramis, 2016).

Dari diatas mengindikasikan isolasi sosial adalah salah satu perubahan yang muncul pada skizofrenia. Isolasi sosial adalah suatu pengalaman menyendiri dari seseorang dan perasaan segan terhadap orang lain sebagai sesuatu yang negatif atau keadaan yang mengancam (Nanda, 2005).

Secara medis tidak ada penggolongan untuk masalah gangguan isolasi sosial. Isoalasi sosial menjadi tanda dan gejala dari gangguan jiwa. Tanda gejala utama klien dengan episode depresi adalah sedih yang mendalam, berkurangnya energi dan menurunnya aktivitas gejala tambahan yang meliputi adalah harga diri rendah, kepercayaan diri kurang, rasa bersalah, pesimis, tidur terganggu, tidak nafsu makan (Nanda, 2005).

Isolasi sosial tidak hanya berdampak secara individu pada klien yang mengalami tetapi juaga pada sistim klien secara keseluruhan yaitu keluarga dan lingkungan sosialnya. Isolasi sosial dapat menurunkan produktifitas atau berdampak buruk pada fungsi di tempat kerja, karena kecenderungan klien menarik diri dari peran dan fungsi sebelum sakit.

Menurut Hawari (2003) salah satu kendala dalam upaya penyembuhan pasien gangguan jiwa adalah pengetahuan masyarakat dan keluarga. Keluarga dan masyarakat menganggap gangguan jiwa penyakit yang memalukan dan membawa aib bagi keluarga. Penilaian masyarakat terhadap gangguan jiwa sebagai akibat dilanggarnya larangan, guna-guna, santet, kutukan dan sejenisnya berdasarkan kepercayaan supranatural. Dampak dari kepercayaan tersebut, upaya pengobatan pasien dengan gangguan jiwa dibawa ke dukun atau paranormal. Selain itu perlakuan yang diterima oleh pasien gangguan jiwa seperti disembunyikan, diisolasi, dikucilkan bahkan sampai dipasung semakin memperberat kondisi pasien (Hawari, 2003; dalam Wiyati et al., 2010).

Berdasarkan data awal yang diperoleh dari rekam medis dan observasi di RSKJ Soeprapto Provinsi Bengkulu terdapat jumlah pasien gangguan jiwa di RSKJ Soeprapto Provinsi Bengkulu pada tahun 2015 berjumlah 1.962. Pada tahun 2016 mengalami penurunan berjumlah 1.962 dengan jumlah pasien skizofrenia yaitu berjumlah 670 orang, 230 orang diantaranya mengalami gangguan isolasi sosial. Pada akhir tahun 2016 tercatat ada 97 Pasien gangguan isolasi sosial yang sudah bisa pulang, tapi harus menjalani rawat jalan. Pasien RSKJ Soeprapto Bengkulu sudah banyak yang pulang kerumah, akan tetapi masih dalam perawatan keluarga yang mendampingi pasien tersebut, karna ditakutkan mengalami kekambuhan kembali. 
Dari survei awal yang dilakukan peneliti di temukan selama 2 hari wawancara kepada 3 orang keluarga yang memiliki pasien yang menjalani rawat jalan di RSKJ Soeprapto Bengkulu. Ketiga orang keluarga tersebut tidak mampu melakukan keperawatan kepada klien yang mengalami isolasi sosial.

\section{METODE PENELITIAN}

\section{Jenis Dan Rancangan Penelitian}

Desain penelitian yang digunakan dalam penelitian ini adalah pre-experimen dengan penelitian one-group pre-test and post-test design dimana penelitian ini dilakukan dengan cara memberikan pre-test (pengamatan awal) terlebih dahulu sebelum diberikan intervensi/perlakuan kemudian diberikan perlakuan edukasi keluarga, selanjutnya dilakukan observasi kedua (post-test) yaitu sesudah diberikan intervensi. Penelitian ini akan dilakukan dirumah keluarga pasien isolasi sosial yang menjalani rawat jalan pada RSKJ Soeprapto Bengkulu, waktu penelitian telah dilaksanakan pada bulan 20 Januari sampai 3 Februari 2018.

Populasi dalam penelitian ini adalah seluruh keluarga yang memiliki pasien rawat jalan di RSKJ Soeprapto di Kota Bengkulu yang berdomisili di Kota Bengkulu. Sampel pada penelitian adalah keluarga memiliki pasien rawat jalan di RSKJ Soeprapto di Kota Bengkulu yang berdomisili di Kota Bengkulu berjumlah 15 orang. Teknik sampling dalam penelitian ini adalah menggunakan purposive sampling berdasarkan beberapa kriteria, antara lain: keluarga pasien isolasi sosial yang pernah rawat inap di RSKJ Soeprapto Bengkulu, keluarga yang paling dekat dengan pasien, dapat melihat dan mendengar, keluarga yang merawat pasien isolasi sosial dengan cara rawat jalan dan bersedia menjadi responden.

\section{Prosedur Penelitian}

Pelaksanaan penelitian ini yang pertama yaitu peneliti mengurus surat izin, meminta izin dari institusi pendidikan yaitu Program Sarjana llmu Keperawatan Universitas Muhammadiyah Bengkulu, setelah mendapat surat izin penelitian kemudian langsung diserahkan ke bagian Dinas Penanaman Modal dan Pelayanan Terpadu Satu Pintu (DPMPTSP) Provinsi Bengkulu, kemudian dirujuk oleh DPMPTSP Provinsi Bengkulu ke Bagian Kepala Direktur RSKJS Provinsi Bengkulu. Setelah mendapat surat izin penelitian dari RSKJS Provinsi Bengkulu, peneliti langsung menyerahkan surat dan meminta izin ke poli rawat jalan dan langung mencari sampel penelitian. Peneliti mencari sampel yang sesuai dengan kriteria inklusi yang telah ditetapkan oleh peneliti dan untuk dokumentasi penelitian mencari sampel dan penelitian dirumah keluarga pasien dengan gangguan isolasi sosial ditemani oleh teman-teman.

Selain menggunakan kriteria inklusi peneliti juga bertanya langsung kepada responden apa penyebab salah satu keluarganya masuk ke RSKJ Provinsi Bengkulu, setelah keluarga pasien menjawab pertanyaan yang sesuai dengan apa yang peneliti harapkan yaitu keluarga yang memiliki pasien dengan gangguan isolasi sosial maka keluarga pasien itulah yang dijadikan sampel. Setelah keluarga responden menyutujui dan bersedia menjadi sampel, peneliti meminta identitas pasien seperti alamat lengkap rumah pasien dan nomor handphone, kemudian peneliti mencari rumah responden tersebut. Penelitian dilakukan mulai bulan maret 2018, penelitian ini dilakukan di rumah keluarga pasien dengan ganguan isolasi sosial, peneliti memberikan kuisioner 
pretest kemampuan keluarga tentang gangguan isolasi sosial. untuk melihat bagaimana kemampuan keluarga tentang pasien dengan gangguan isolasi sosial sebelum diberikan edukasi keluarga. Setelah itu peneliti memberikan edukasi kepada salah satu keluarga yang paling dekat dengan pasien ganguan isolasi sosial, kemudian setelah, di berikan edukasi kepada keluarga yang akan diteliti, selanjutnya 2 hari setelah itu peneliti memberikan kuisioner yang sama yaitu kuisoner post test kemampuan keluarga tentang pasien ganguan isolasi sosial.

\section{Teknik Analisa Data \\ Analisa Univariat}

Analisis univariat dilakukan untuk mendeskripsikan karakteristik setiap variabel penelitian, diantaranya karakteristik klien dan keluarga (usia keluarga, jenis kelamin, tingkat pendidikan dan riwayat pekerjan, lama klien pulang dari rumah sakit dan frekuensi kekambuhan). Dengan isolasi sosial pada klien dan kemampuan klien dan kemampuan keluarga dalam merawat merupakan data numerik yang dianalisis untuk menghitung mean, median, standar deviasi, confidence interval 95\%, nilai maksimal dan minimal. Penyajian data masing-masing variabel dan diinterpretasikan berdasarkan hasil yang diperoleh.

\section{Analisis Bivariat}

Analisis bivariat digunakan untuk melihat perbedaan kemampuan keluarga dalam merawat klien yang mengalami isolasi sosial sebelum dan setelah diberikan edukasi di RSKJ Soeprapto Bengkulu. Uji statistik yang digunakan adalah dependent T-test. Derajat kepercayaan yang digunakan adalah 95\% $(\alpha=0,05)$. Jika $p$-value lebih kecil dari $\alpha(\rho<0,05)$, artinya ada perbedaan kemampuan keluarga dalam merawat klien yang mengalami isolasi sosial sebelum dan setelah diberikan edukasi di RSKJ Soeprapto Bengkulu.

\section{HASIL PENELITIAN \\ Karakteristik Responden}

Deskripsi karakteristik responden adalah menguraikan atau memberikan gambaran mengenai identitas responden dalam penelitian ini, sebab dengan menguraikan identitas responden yang menjadi sampel dalam penelitian ini maka akan dapat diketahui sejauh mana identitas responden dalam penelitian ini. Oleh karena itulah deskripsi identitas responden dalam penelitian ini dapat dikelompokkan menjadi beberapa kelompok yaitu : usia responden,tingkat pendidikan, dan jenis kelamin.

Tabel. 1

Distribusi Frekuensi Umur Keluarga dengan Pasien Ganguan Isolasi Sosial

\begin{tabular}{ccc}
\hline Umur $(\mathrm{Th})$ & Jumlah $(\mathrm{N})$ & Persentase $(\%)$ \\
\hline $20-40$ & 11 & 73,3 \\
$41-60$ & 4 & 26,7 \\
\hline Total & 15 & 100 \\
\hline
\end{tabular}

Berdasarkan tabel 1 didapatkan frekuensi umur pada keluarga dengan pasien ganguan isolasi sosial terbanyak pada usia 20-40 tahun yaitu 11orang $(73,3 \%)$ dan usia paling sedikit pada usia 41-60 yaitu 4 orang $(26,7 \%)$. 
Tabel. 2

Distribusi Frekuensi Pendidikan Keluarga dengan Pasien Ganguan Isolasi Sosial

\begin{tabular}{ccc}
\hline Pendidikan & Jumlah $(\mathrm{N})$ & Presentase $(\%)$ \\
\hline SD & 2 & 13,3 \\
MP & 3 & 20.0 \\
SMA & 8 & 53,3 \\
Perguruan Tinggi & 2 & 13,3 \\
\hline Total & 15 & 100 \\
\hline
\end{tabular}

Berdasarkan tabel 2 didapatkan bahwa sebagian besar pendidikan keluarga dengan pasien ganguan isolasi sosial berpendidikan SMA dengan jumlah 8 Orang $(53,3 \%)$.

Tabel. 3

Distribusi Frekuensi Jenis Kelamin Keluarga dengan Pasien Ganguan Isolasi Sosial

\begin{tabular}{ccc}
\hline Jenis kelamin & Jumlah (N) & Persentase (o/o) \\
\hline Laki-laki & 8 & 53 \\
Perempuan & 7 & 47 \\
\hline Total & 15 & 100 \\
\hline
\end{tabular}

Berdasarkan tabel 3 didapatkan bahwa sebagian besar keluarga dengan pasien ganguan isolasi sosial berjenis kelamin laki-laki dengan jumlah 8 orang (53\%).

Tabel. 4

Distribusi Frekuensi Kemapuan Keluarga dalam Merawat Pasien Gangguan Isolasi Sosial Sebelum Diberikan Edukasi

\begin{tabular}{ccc}
\hline Kemampuan Keluarga (PreTest) & Jumlah (N) & Persentase (o/o) \\
\hline Mampu & 4 & 26 \\
Tidak Mampu & 11 & 74 \\
\hline Total & 15 & 100 \\
\hline
\end{tabular}

Berdasarkan tabel 4 didapatkan bahwa kemampuan keluarga sebelum diberikan edukasi sebagian besar kemampuannya tidak mampu yaitu 11 orang (74\%).

Tabel. 5

Distribusi Frekuensi Kemampuan Keluarga dalam Merawat Pasien Ganguan Isolasi Sosial Sesudah Diberikan Edukasi

\begin{tabular}{ccc}
\hline Kemampuan Keluarga (Post Test) & Jumlah (N) & Persentase (\%) \\
\hline Mampu & 12 & 80 \\
Tidak Mampu & 3 & 20 \\
\hline Total & 15 & 100 \\
\hline
\end{tabular}

Berdasarkan tabel 5 didapatkan bahwa sebagian besar kemampuan keluarga meningkat setelah diberikan intervensi edukasi keluarga. Kemampuan keluarga meningkat menjadi mampu sebanyak 12 orang (80\%). 
Tabel. 6

Pengaruh Edukasi Keluarga terhadap Kemampuan Keluarga dalam Merawat Pasien Ganguan Isolasi Sosial

\begin{tabular}{ccccc}
\hline Variabel & Mean & Std. Deviation & P value & $\mathrm{N}$ \\
\hline Sebelum - Sesudah & 2,66667 & 2.410295 & 0,001 & 15 \\
\hline
\end{tabular}

Berdasarkan tabel 6 berdasarkan uji analisis didapatkan $P$ value $0,001 \quad(<0,05)$, $\mathrm{P}$ value $<0,05$ (95\% kepercayaan), maka ada pengaruh edukasi keluarga terhadap kemampuan keluarga dalam merawat pasien dengan gangguan isolasi sosial di RSKJS Provinsi Bengkulu.

\section{PEMBAHASAN}

\section{Kemampuan Keluarga Sebelum Diberikan Edukasi}

Berdasarkan hasil penelitian menunjukkan bahwa dari 15 keluarga yang diteliti, didapatkan sebagian besar keluarga yang tidak mampu. Dari hasil penelitian, sebelum diberikan edukasi keluarga sebagian besar kurang mampu merawat pasien isolasi sosial. Banyak keluarga mengatakan jika sangat sulit untuk mengatasi bagaimana cara yang tepat yang harus mereka lakukan agar mereka bisa tahu apa dan bagaimana yang harus dilakukan jika salah satu anggota yang mengalami isolasi sosial, keluarga juga stress karena ada salah satu anggota keluarganya yang mengalami gangguan jiwa isolasi sosial.

Menurut Hawari (2003) salah satu kendala dalam upaya penyembuhan pasien gangguan jiwa adalah pengetahuan masyarakat dan keluarga. Keluarga dan masyarakat menganggap gangguan jiwa penyakit yang memalukan dan membawa aib bagi keluarga. Penilaian masyarakat terhadap gangguan jiwa sebagai akibat dilanggarnya larangan, guna-guna, santet, kutukan dan sejenisnya berdasarkan kepercayaan supranatural.

Menurut pendapat Notoatmodjo (2012) yang mengatakan bahwa salah satu faktor yang mempengaruhi kemampuan adalah pendidikan. Pada umumnya pendidikan itu akan mempertinggi taraf intelegensi individu tersebut. Data ini juga didukung oleh hasil penelitian Wiguna \& Ibrahim (2003) dimana dalam penelitiannya dinyatakan bahwa salah satu hal yang penting bagi keluarga adalah mencari kemampuan sebanyakbanyaknya tentang gangguan isolasi sosial sehingga keluarga memiliki keterampilan menghadapi gejala perilaku isolasi sosial. Dalam penelitiannya juga dijelaskan bahwa banyak hal yang dapat meningkatkan terjadinya kekambuhan yang harus keluarga ketahui.

Sesuai dengan penelitian menurut Arsyad (2014) yang mengatakan bahwa hasil penelitiannya menunjukkan bahwa kemampuan responden tentang perawatan anggota keluarga dengan gangguan isolasi sosial dirumah adalah kurang yakni sebanyak 15 responden $(45,5 \%)$, cukup yakni sebanyak 9 responden $(27,3 \%)$ dan baik yakni sebanyak 9 responden $(27,3 \%)$. Hampir separuh responden memiliki kemampuan yang kurang, sehingga dikawatirkan hal ini akan menyulitkan keluarga dalam mengatasi, menjaga serta merawat salah satu keluarga mereka mengalami isolasi sosial. Hasil penelitian diatas memberi informasi bahwa masih banyak keluarga yang memiliki kemampuan rendah dalam merawat klien isolasi sosial. 


\section{Kemampuan Keluarga Sesudah Diberikan Edukasi}

Berdasarkan hasil penelitian dapat dilihat bahwa setelah diberikan edukasi pada keluarga dengan dengan pasien ganguan isolasi sosial dari 15 responden sebagian besar mengalami peningkatan kemampuan menjadi mampu dengan menjawab pertanyaan, jawaban yang benar yaitu sebanyak 12orang (80\%). Dari penelitian ini menunjukkan bahwa adanya peningkatan mengenai kemampuan keluarga dalam merawat pasien dengan gangguan isolasi sosial, didapat bahwa jumlah responden sebelum diberikan edukasi.

Menurut Notoatmodjo (2012) informasi yang diperoleh baik dari pendidikan formal maupun non formal dapat memberikan pengaruh jangka pendek sehingga menghasilkan perubahan atau peningkatan kemampuan. Pendidikan non formal tersebut dapat mempengaruhi kemampuan keluarga tentang cara merawat pasien ganguan isolasi sosial menjadi tinggi.

Hasil post test ini sesuai dengan penelitian sebelumnya dari Keliat \& Akemat (2010) pada hasil penelitian ini didapatkan bahwa mayoritas responden memiliki kemampuan sedang yaitu $67,0 \%$ atau 69 orang dan tinggi $33,0 \%$ atau 34 orang. Sastroasmoro (2011) mendukung penelitian ini yang menyebutkan bahwa tingkat kemampuan pada keluarga pasien skizofrenia sebagian besar adalah tinggi $(55,6 \%)$. Hal ini dimungkinkan keluarga sering mendapatkan informasi maupun pendidikan kesehatan tentang cara merawat pasien ganguan isolasi sosial dari petugas kesehatan.

Setelah diberikan tindakan berupa edukasi pada keluarga kemampuan keluarga semakin meningkat dari sebelumnya, pendidikan kesehatan yang diberikan menggunakan lembar balik. Pendidikan kesehatan merupakan serangkaian upaya yang ditujukan untuk mempengaruhi orang lain, mulai dari individu, kelompok, keluarga dan masyarakat agar terlaksananya perilaku hidup sehat (Mubarak, 2009). Sama halnya dalam proses pembelajaran pendidikan kesehatan memiliki tujuan yang sama yaitu terjadinya perubahan perilaku yang dipengaruhi banyak faktor diantaranya adalah sasaran pendidikan, pelaku pendidikan, proses pendidikan, dan perubaban perilaku yang diharapkan seseorang yang memperoleh informasi lebih banyak maka kemampuannya semakin luas (Setiawati, 2008).

Dapat disimpulkan bahwa jika kemampuan keluarga tinggi maka akan meningkatkan kemampuan keluarga dalam memberikan perawatan pada pasien ganguan isolasi sosial yang hasilnya pun akan menjadi optimal.

Menurut Hawari (2003) salah satu kendala dalam upaya penyembuhan pasien gangguan jiwa adalah pengetahuan masyarakat dan keluarga. Keluarga dan masyarakat menganggap gangguan jiwa penyakit yang memalukan dan membawa aib bagi keluarga. Penilaian masyarakat terhadap gangguan jiwa sebagai akibat dilanggarnya larangan, guna-guna, santet, kutukan dan sejenisnya berdasarkan kepercayaan supranatural. Dampak dari kepercayaan tersebut, upaya pengobatan pasien dengan gangguan jiwa dibawa ke dukun atau paranormal. Selain itu perlakuan yang diterima oleh pasien gangguan jiwa seperti disembunyikan, diisolasi, dikucilkan bahkan sampai dipasung semakin memperberat kondisi pasien (Hawari, 2003; dalam Wiyati et al., 2010). 


\section{Pengaruh Edukasi Keluarga terhadap Kemampuan Keluarga dalam Merawat Pasien Ganguan Isolasi Sosial}

Berdasarkan hasil penelitian menunjukkan bahwa ada pengaruh edukasi keluarga terhadap kemampuan keluarga dalam merawat pasien dengan gangguan isolasi sosial Di Rumah Sakit Khusus Jiwa Soperapto (RSKJS) Provinsi Bengkulu. Peningkatan kemampuan keluarga terjadi karena diberikannya edukasi keluarga tentang merawat pasien dengan gangguan isolasi sosial maka keluarga dapat mengingat dan memahami informasi/kemampuan yang diberikan melalui pendidikan kesehatan.

Memberikan pendidikan kesehatan dapat menambah kemampuan kepada individu, keluarga dan masyarakat lainnya. Notoatmodjo (2012) mengemukakan kemampuan adalah hasil dari tahu dan ini terjadi setelah orang melakukan pengindraan pada suatu objek tertentu. Penelitian ini sesuai dengan penelitian yang dilakukan Ahyar (2010) yang menunjukkan bahwa adanya pengaruh pendidikan kesehatan tentang ganguan isolasi sosial terhadap kemampuan keluarga dalam merawat pasien ganguan isolasi sosial, pelaksanaan pendidikan kesehatan tentang ganguan isolasi sosial merupakan penyampaian informasi sehingga mampu mempengaruhi kemampuan keluarga dengan nilai t-tests 2,834 dalam merawat pasien ganguan isolasi sosial. Kemampuan keluarga mengenai ganguan isolasi sosial sangat diperfukan agar keluarga dapat merawat pasien dengan benar.

Menurut penelitian sebelumnya dari Ahyar (2010) ditemukan ada pengaruh edukasi dalam menurunkan beban keluarga dan meningkatkan kemampuan keluarga dalam merawat klien dengan halusinasi. Penelitian yang dilakukan oleh Sari menjelaskan bahwa ada pengaruh yang bermakna meningkatkan kemampuan kognitif dan psikomotor keluarga dalam merawat klien dengan dipasung. Menurut teori dari Notoatmodjo (2012) pendidikan merupakan faktor yang berpengaruh terhadap kemampuan. Dengan demikian, pendidikan seseorang yang semakin tinggi maka kemampuannya juga akan semakin tinggi. Sebagaimana yang peneliti lihat pendidikan yang tinggi akan mempengaruhi kemampuan yang semakin banyak dan semakin luas. Hal ini juga disampaikan oleh penelitian sebelumnya Wiyati et al., (2010) yang mengatakan hasil penelitian yang didapat nilai $\mathrm{P}$ value $=0,0001$ artinya ada perbedaan yang bermakna kemampuan kognitif dan psikomotor pada kelompok intervensi sebelum dan sesudah dilakukan psikoedukasi keluarga.

Lawrence \& Veronika (2002); dalam Wiyati et al., (2010) mengungkapkan terjadi peningkatan $33 \%$ pada kelompok pasien skizofrenia setelah diberikan terapi psikoedukasi keluarga, karena dalam psikoedukasi keluarga menjelaskan hubungan positif yang meningkat antara anggota keluarga, manajemen stress keluarga, kemampuan keluarga dalam melakukan role play. Menurut Suny \& King (2007) terapi psiko edukasi keluarga sangat efektif karena memberikan informasi tentang preventif dan promotif, keterampilan koping, kognitif, tingkah laku dan keterampilan bagi keluarga.

\section{SIMPULAN}

Distribusi frekuensi kemampuan keluarga dalam merawat dengan pasien ganguan isolasi sosial sebelum diberikan edukasi menunjukkan bahwa dari 15 keluarga responden didapatkan kemampuan keluarga sebelum diberikan edukasi sebagian besar tidak mampu merawat pasien. Distribusi frekuensi kemampuan keluarga dalam merawat dengan pasien ganguan isolasi sosial sesudah diberikan edukasi dapat dilihat bahwa dari 15 responden sebagian besar mengalami peningkatan kemampuan setelah 
diberikan intervensi edukasi keluarga. Kemampuan keluarga dalam merawat pasien isolasi sosial meningkat yang mampu merawat pasien. Ada pengaruh edukasi keluarga terhadap kemampuan keluarga dalam merawat pasien dengan ganguan isolasi sosial di RSKJ Soeprapto Bengkulu.

\section{SARAN}

\section{Universitas Muhammadiyah Bengkulu}

Diharapkan nantinya kepada seluruh mahasiswa terutama pada mahasiswa keperawatan dapat menjadikan informasi tambahan dan bisa di manfaatkan sebagai acuan/pedoman dalam pembuatan skripsi selanjutnya mengenai merawat pasien dengan ganguan isolasi sosial

\section{Rumah Sakit Khusus Jiwa Soeprapto Provinsi Bengkulu}

Memberikan informasi terkait tentang ganguan isolasi sosial pada keluarga dalam merawatpasien ganguan isolasi sosial pada saat keluarga berkunjung ke Rumah Sakit.

\section{Keluarga Pasien}

Kemampuan ini dapat diterapkan dirumah keluarga yang memiliki pasien dengan riwayat gangguan isolasi sosial dan lebih memahami tentang bagaimana cara yang tepat dilakukan dalam merawat pasien ganguan isolasi sosial.

\section{Peneliti Selanjutnya}

Diharapkan kepada peneliti selanjutnya dapat melanjutkan penelitian ini dengan menggunakan kelompok kontrol, perlu melakukan penelitian lebih lanjut mengenai faktor-faktor seperti faktor ekonomi, proses komunikasi dalam keluarga dan perhatian keluarga serta diharapkan adanya tindakan penyebaran leaflet mengenai cara perawatan pasien dengan ganguan isolasi sosial selama di rumah kepada pihak keluarga yang berkunjung.

\section{DAFTAR PUSTAKA}

Ahyar, S. (2010). Konsep Diri dan Mekanisme Koping dalam Aplikasi Proses Keperawatan. Diakses 19 April

Arsyad, A. (2014). Proses Keperawatan Aplikasi Model Konseptual. Jakarta: EGC

Depkes RI. (2010). Profil Kesehatan Indonesia. Jakarta: Depkes RI

Dermawan, D., \& Rusdi, R. (2013). Keperawatan Jiwa: Konsep dan Kerangka Kerja Asuhan Keperawatan Jiwa. Yogyakarta: Gosyen Publishing

Hawari, H. (2003). Pendekatan Holistik pada Gangguan Jiwa Skizofrenia. Jakarta: Gaya Baru

Keliat, B. A. \& Akemat, A. (2010). Model Praktik Keperawatan Profesional Jiwa. Jakarta: EGC

Maramis, M. (2016). Pengantar Psikologis Klinis. Bandung: PT Refika Aditama

Mubarak, I. M. (2009). Ilmu Keperawatan Komunitas: Konsep dan Aplikasi. Jakarta: Salemba Medika

Nanda, M. (2005). Keperawatan Kesehatan Komunitas Teori dan Praktik dalam Keperawatan. Jakarta: Salemba Medika

Notoatmodjo, S. (2012). Pendidikan dan Perilaku Kesehatan. Jakarta: PT. Rineka Cipta

Sastroasmoro, Y. (2011) . Buku Ajar Konsep Dasar Keperawatan Jiwa. Jakarta: EGC 
Setiawati, S. (2008) . Asuhan Keperawatan Keluarga Aplikasi dalam Praktik. Jakarta : EGC

Suny, S \& King, W. (2007). Psychoeducational Programme in Hong Kong for People with Schizofrenia. Occup.Ther. Int, 14(2), 86-98

Wiguna, I. M. S., \& Ibrahim, A. S. (2003). Perbandingan Gangguan Ansietas dengan Beberapa Karakteristik Demografi pada Wanita Usia 15-55 Tahun. J Kedokter Trisakti, 22(3), 87-91

Wiyati, R., Wahyuningsih, D., \& Widayanti, E. D. (2010). Pengaruh Psikoedukasi Keluarga terhadap Kemampuan Keluarga dalam Merawat Klien Isolasi Sosial. Jurnal Keperawatan Soedirman (The Soedirman Journal og Nursing), 5(2), 85-94 